\title{
Ingesting power
}

\section{Ingerir poder}

\author{
Eva Marxen Post ${ }^{1}$ \\ Adam Greteman Harms ${ }^{2}$
}

\begin{abstract}
This paper starts with Foucault's ideas about social control and how they were further developed in Preciado's Testo Junkie exploring the ingesting power through various pharmaceutical technologies. The shift from disciplinary control to the much subtler pharmaceutical control will be analyzed within the context of the university. In particular, we will focus on this emerging form of biopower thinking through its implications teaching within the fields of art therapy and teacher education. Taking into account the steady increase of (mental) health diagnoses on college campuses, professor's responses, the possibilities of actions, and the pedagogical implications will be debated. Within blurring borders of health and education, how do professors and students encounter education in different ways? An institutional critique of health and education seems necessary in this context. Issues of unease, disease, social class and entitlement will refer us back to Foucault and his work about avowal, truth, and power.
\end{abstract}

\section{Keywords}

Biopower, social control, education, pharmaceutical technologies.

\footnotetext{
${ }^{1}$ Eva Marxen Post. Assistant Professor, Art Therapy Department, School of the Art Institute of Chicago (SAIC), USA. Ph.D. and DEA in Anthropology from the UniversityRovira i Virgili, Tarragona, Spain; MA in Art Therapy from the University of Barcelona, and MA in Psychoanalytical Psychotherapy from the Center of Diagnosis and Psychotherapy of Barcelona. E-mail: emarxen@saic.edu ID: http://orcid.org/0000-0002-2140-4982
}

2 Adam J. Greteman. Director of the Master of Arts in Teaching and an Assistant Professor of Art Education at the School of the Art Institute of Chicago, USA. Ph.D. from Michigan State University in Curriculum, Instruction and Teacher Education and BA from Creighton University in Psychology. E-mail: agreteman@saic.edu ID: http://orcid.org/0000-0003-0115-3386 
RECIE. Revista Electrónica Científica de Investigación Educativa Vol. 4, núm. 2, enero-diciembre 2019, pp. 875-886.

\section{Resumen}

El presente trabajo comienza con las ideas de Foucault sobre el control social y cómo se desarrollaron más extensamente en Testo Junkie de Paul Preciado, explorando la capacidad de ingestión del poder a través de diversas tecnologías farmacéuticas. El cambio del control disciplinario al mucho más sutil control farmacéutico será analizado dentro del contexto de la universidad. En particular, ponemos énfasis en esta forma emergente de biopoder, incluyendo las implicaciones en la enseñanza dentro de los campos de la arteterapia y la educación del profesorado. Teniendo en cuenta el aumento constante de diagnósticos de salud (mental) en los campus universitarios, se debatirán las respuestas de los profesores, las posibilidades de acción y las implicaciones pedagógicas. Dentro de las fronteras difusas de la salud y la educación, ¿cómo los profesores y los estudiantes se encuentran con la educación de diferentes maneras? Una crítica institucional de la salud y la educación parece necesaria en este contexto. Los asuntos de aflicción, enfermedad, clase social y derecho nos remitirán a Foucault y su trabajo sobre la confesión, la verdad y el poder.

\section{Palabras clave}

Biopoder, control social, educación, tecnologías farmacéuticas.

\section{Introduction}

We are being confronted by, according to Paul Preciado (2013) "a new kind of hot, psychotropic punk capitalism" (p. 33). And this new kind of capitalism and its attendant transformations are, as he articulated "imposing an ensemble of new microprosthetic mechanisms of control of subjectivity by means of biomolecular and multimedia technical protocols"(p. 33). There is an ongoing shift, to put it differently, in how we understand and inhabit subjectivity tied to the evolution and proliferation of pharmaceuticals (e.g., Ritalin, Viagra, PrEP) and technologies of transmission (e.g., the Internet, Phone Apps). No longer are subjects defined and understood through the lexicon of 20th century discourses that sought to uncover the truths of one's "being," rather subjects are invented through the interlacing of one's being and the technological, cultural, political contexts one inhabits. "This life," according to Preciado, "cannot be understood as a biological given; it does not exist outside the interlacing of production and culture that belongs to technoscience" (p. 43). Life as it intersects with production and culture to become a life happens within institutions and how those institutions, notably schools and universities for 
our purposes, come to make sense and use of the lives of those involved, such as students and teachers.

Preciado develops further Foucault's ideas about social control and how it is exercised in various institutions including those of health and penalty and education. However, nowadays a shift has taken place from discipline to the much subtler form of biopolitical control in education and society at large. This shifts the panopticon from a purely externalized mode of control to a internalized mode whereby subjects ingest power and through such ingestion can, via emerging medical technologies (such as apps), mine health to provide quantitative data. This new regime is one that "refers to the process of a biomolecular (pharmaco) and semiotic-technical (pornographic) government of sexual subjectivity" (p. 34). Preciado's focus on sexual subjectivity is of importance since, in his estimation, critical theory of the 20th and 21st century "stopped biopolitically at the belt" (p. 37) preferring to focus on cognition, language and the symbolic. Absent from such theory is the material - the work of material substances, in particular - on how subjects came to be. Providing a rather extensive history of the invention of synthetic hormones and other biomolecular substances, Preciado mapped out the ways in which subjectivity had always already, for much of the 20th century, been invented through the ingestion of molecules developed through pharmaceutical and medical research.

For Joseph Dumit (2012), there has been a shift where the use of pharmaceuticals has become the work of life. His aptly titled Drugs for Life mapped out the political, economic, and medical realities of pharmaceutical use to assist and redefine the work of living. "To be normal," as Dumit noted, "is to have symptoms and risk factors you should worry about, and at the same time to not know whether you should be worrying about yet more things" (p. 1). Such healthy living is defined through attention to risk reduction and prevention, along side the possible use of new pharmaceuticals to address such "concerns." Similar to Preciado, Dumit contended that pharmaceuticals have experienced a shift in use so much so that they come to dominate how we understand being healthy; to be healthy is to be on various medications.

Life has become not only medicalized, but more narrowly phamacalized. For Horwitz (2010), in "Pharmaceuticals and the Medicalization of Everyday Life" he pointed out the most dramatic recent changes in medicalization have occurred among children and adolescents. The past decade, in particular, has seen an explosive growth in the use of pharmaceuticals to control behavioral and emotional problems among the young. Especially serious risks accompany the increasing medicalization of 
childhood troubles as children become controlled and surveilled externally and internally.

These changes have occurred and continue to impact the ways in which students and educators enter classrooms. As such, an institutional critique of health and education is necessary in this context so that we can unpack these ways of framing subjects alongside the work of becoming subjects. Issues of unease, disease, social class and entitlement will refer us back to Foucault and his work about avowal, truth, and power as they are refracted through the evolving ingestion of pharmaceutical compounds to address contemporary modes of being in the world; modes of being explored and inhabited within school.

Of particular interest to us is the landscape of education, both regular and higher education, and the implications for the educational project as it encounters, what Preciado names this new kind of capitalism, the "pharmacopornographic era." This includes the role of pharmaceuticals in defining or perhaps more likely inventing new student subjects including the Ritalin-Student-Subject and the Hormone Therapy-Student-Subject. While on the face of things it might be easy to see how such subjects are problematic as they become invested in and tied to pharmaceutical companies and their profit motives, medicalized discourses, and educational initiatives, it also remains the case that such pharmaceuticals provide for new ways of becoming a subject, amidst the conditions of late capitalism.

Turning specifically to two contemporary issues in education Attention Deficit Hyperactivity Disorder (ADHD) and the use of genderaffirming hormones - we offer a preliminary investigation on these subjects and their educational impact and import. It is rooted in analyzing not only the experience of working with youth in a museum public program in Barcelona, Spain, but also the discourses surrounding and framing the experiences of gender in United States schools.

\section{The Hormone-Therapy-Subject}

Preciado (2013) mapped out the history of synthetic hormones, including the racist and eugenic realities that were a part of their development. Yet, within this, Preciado also illustrated the ways the biomolecular structures of synthetic hormones have evolved alongside the 20th century subject to expand gendered possibilities. While 20th century subjects are very well defined by the histories of "identity" - race, gender, class, sexuality and so forth - the 21st century has seen these identities upended and reconfigured as there has been a turn, or arguably, a return to materiality. The materiality 
of ingesting chemical substances and the impact such ingestion on our becoming has become, we suggest, a necessary component in contemplating the educational project. Or put differently, as professors we have to contemplate the ways in which pharmaceuticals are impacting our selves, student bodies, and the responses that emerge within and through learning - either learning about new subjects or encountering new subjects within the classroom. This contemplation is not necessarily unique - the ingestion of substances has been a component of education life for much of the $20^{\text {th }}$ and $21^{\text {st }}$ centuries in the form of both illicit (e.g., cocaine, LSD) and prescription drugs. Rather, the shift is in the normalization of ingestion via "expert" medical practitioners in ways that also expand (precariously so) ways of inhabiting a body.

This can be seen in the expanding ideas about gender beyond the binary. In 2007, Barbara Walters for 20/20 offered a glimpse, one of the first on mainstream US television, into the lives of transgender youth and their families. Within the interview, Walters talked with Jazz Jennings and her family. Jazz, at the time five years old, would go on to become a trans youth advocate and the star of her own television show I Am Jazz. Within this show exploring Jazz's life and navigation of becoming trans through adolescence, the issue of hormone therapy is brought front-and-center. For trans youth and adolescents puberty is often a moment where particular physiological changes occur that are at odds with one's emerging sense of self. The process - which lies beyond the scope of our paper - is primarily directed by medical practitioners who are themselves working to figure out appropriate and ethical ways to tarry between social, cultural, psychological and physiological realities (Olson-Kennedy, Rosenthal, Hastings, \& Wesp, 2018). What is central to these decisions and discussions is the ways to utilize hormones to affirm one's gender when there exists a disconnect between one's body and one's sense of self; a disconnect that can lead to depression, anxiety, and suicide.

While we are not medical practitioners, meaning we leave the medical aspects of doses and age of onset to them, our interest is in how these evolving practices are taken up within educational settings to simultaneously expand gendered possibilities and restrain them. As youth and we explore youth diagnosed with ADHD next - consume or inject various biomolecular or chemical substances, how does education come to understand the needs of these subjects and the influence of such ingestion on their coming into presence? Such concerns and curiosities around trans youth and adolescent health are not opposed to the important strides in medical treatments that affirm the needs of trans individuals. Ingesting 
power - from a Foucaultian (1978) point of view - is neither positive or negative. Rather it is productive in the creation of subjects and their (im)possibilities. Such productions are dangerous, as all productions are. All subjects in schools - trans or cisgender - encounter others - in schools and elsewhere - raising simple questions beyond identities (male and female) and toward pharmaceuticals as it is the ingestion of power that connects students more and more. For educators and their students, in the midst of such changes, we have a responsibility to contemplate and work through the impacts of ingesting power. While the rise of gender-affirming hormones for trans youth speaks to gains in the rights and medical recognition of transgender realities - beyond, although not fully, the pathologizing gaze - there is also the concerns around how youth and adolescents are also prescribed pharmaceuticals to address their behaviors in socially mediated and normalized ways.

\section{The ADHD-subject}

For Horwitz (2010)

Attention Deficit Hyperactivity Disorder (ADHD) has become a highly prevalent psychiatric condition among children and adolescents. ... Most treatment for ADHD involves the use of stimulant drugs, in particular, amphetamines. ...The use of drugs to control children's behavior and emotions, although growing worldwide, is mainly an American phenomenon: the United States uses over $80 \%$ of the world's supply of stimulants.

... The pervasive use of stimulant drugs among children poses several risks. Widespread concern exists that many medicated children do not, in fact, have a psychiatric condition but instead irritate teachers, and frustrate parents. The criteria for ADHD found in the official manual of the psychiatric profession, the Diagnostic and Statistical Manual of Mental Disorders (DSM), are very general and have considerable overlap with natural processes of inattention, distraction, and boisterousness. One leading expert on ADHD estimates that only about $10 \%$ of current youthful users would require medication if they had optimal family and school situations." (pp. 93-94)

We quote, quite extensively from Horowitz, to illustrate the ways ADHD has developed and its relationship to the ingestion of pharmaceuticals.

While Horowitz (2010) documented these changes and their everydayness, in Marxen's work developed with and at the Museum of 
Contemporary Art of Barcelona (MACBA) between 2003-2013 she was able to confirm Horwitz's findings through experience. The public program was based on the use of art therapy with a psychoanalytical slant and an anthropological understanding. It consisted of weekly art therapy groups at educational centers (a public high school and a special school unit for adolescents expelled from public high schools) with teenagers labeled at risk of social exclusion, performing so called antisocial and disruptive behavior as well as behavioral problems.

The psychoanalytical focus of the project was to create the necessary conditions for subjective work aimed at facilitating the capacity for symbolization, primarily according to Winnicott's potential space which allows the participants to symbolize their life experience (Marxen, 2017, 2016, 2012, 2011, 2009, 2008; Marxen \& Rodríguez, 2012). The key element was to provide the therapeutic holding in line with Winnicott, on an institutional level. Following his ideas, the adolescents' assumed antisocial behavior and their behavioral problems stem from social deprivation and lack of emotional holding in early childhood. Instead of labelling their behavior as pathological, the healthy and creative part should be seen, in the sense of being able to provoke and attract the reactions of adults and the society towards their social exclusion (Winnicott, 1984, 1971). Winnicott's psychoanalytic reasoning and its implementation during the MACBA experience does not serve to foster privilege and power, a main critique raised against psychoanalysis when applied in its traditional form (Foucault, 1976; Castel, 1973). The MACBA practice based on Winnicott underlined a social understanding of the unease, transferring the basic function of holding towards the institution. This institutional holding became available for the socio-economically underprivileged and went along with key ideas of the Institutional Therapy including its partly Marxist motivation and psychoanalytical basis. Yet, its main representatives worked in context of psychosis and mental illness (see for example Oury, Guattari, \& Tosquelles, 1985).

Anthropological comprehension implies a critical analysis of both therapy and art. The main objective is to create and maintain spaces of freedom, as opposed to dynamics of normalizations, functionalism, and dominant subjectifications. The latter term is drawn on the one hand from Foucault's political and ethical understanding of subjectification (1984, 1994), an understanding that the process of becoming a subject at the time was dominated by and coping with existing power mechanisms (political) as well as assuming the responsibility for one's acts including one's form of self-care (ethical). On the other hand, it refers to Rolnik's and Deleuze's 
reasoning of the "big dominant health" limited to the functional and pragmatic order, enslaving the subject to the "map of the prevailing sense" and thus producing pathologies (Rolnik, 2001, pp. 5-6; Deleuze and Parnet, 1977). According to the Sociology of Deviance and the Labeling Approach all these are mechanisms and social constructions by which the person is reified in their supposed given situation by the society (Becker, 1963; Goffman, 1963; for a summary of this approach: Bergalli, 1980; furthermore Foucault, 1975, 1961; Taussig, 1992).

Yet, the art therapy practice under question aims at providing responses which differ from those the participants are usually given in their institutional contexts; in the case of the above mentioned adolescents, they were written off by their schools and by society at large as total academic and social failures. In their educational institutions, many teachers and educators have tried to refer them to mental health institutions for treatments and medications according to the supposed Attention Deficit Hyperactivity Disorder (ADHD) but, in this context, the young people's very strong resistance towards mental health treatments should be stressed as a possible intuition of refusing to be institutionalized by the dominant medical discourse. Likewise, it is a fact that by a one- school-term process of the described manner of art therapy and without any medication the teenagers' attention does not show any deficit at all (see for the deconstruction of the ADHD and a very critical view on over-medication Horwitz, 2010; Knobel Freud, 2013; Valverde Eizaguirre, 2015).

The art therapy practice should be freed from the dominant discourse of hegemony and its penetration in Gramsci's sense; for example not to accept uncritically the dominant medical discourse and its diagnosis (i.e. the ADHD). The attitude of the art therapist and their critical stance towards dominant discourses in art and therapy is paramount. In addition, this includes the serious and radical acceptance of the participants' knowledge and likewise their style of verbal and artistic expression.

Gramsci had already considered disease as a social-political process, as an incorporation of inequality. Following his reasoning, the body constitutes a terrain of hegemonic conflicts. Furthermore and like Goffman (1961) as well as Foucault (1961), he unmasked psychopathology as a social and political construct intended to limit marginalized people's social action and participation (Gramsci, 1975; Pizza, 2005).

In this potential space of art therapy, participants can feel accepted and comfortable enough to create their narratives in order to deconstruct institutionalized lives and situations of domination. Their agency as a 
capacity of auto-determination should be strengthened. In line with the ideas of Deleuze and Guattari (1975) on minor language located at the edge of the dominating discourse, in the potential art therapy space the participants' narratives can activate their hidden potential beyond the majority thinking and its mechanisms of marginalization and labelling. New horizons and alternatives are thus opened. Negri and Guattari (1996) had already stressed the capacity of marginalized subjectivities to find new ways of articulation and creation. The ideas of these authors coincide with the described art therapy experience: despite the marginalization of the young people, their expressions were much more embodied than ideological. They articulated their lived and embodied experience (also Foucault, 2001; Marxen, 2016 and 2017).

\section{Concluding remarks}

Let's end with Preciado, who in articulating a 21st century philosophy of sex, sexuality, gender, and more, sought to draw difference together, moving beyond 20th century concepts towards those invented via technoscience. As Preciado noted, drawing attention to his relationship to testosterone:

My ambition is to convince you that you are like me. Tempted by the same chemical abuse. You have it in you: you think that you're cisfemales, but you take the Pill; or you think you're cis-males, but you take Viagra; you're normal, and you take Prozac or Paxil in the hope that something will free you from your problems of decreased vitality, and you've shot cortisone and cocaine, taken alcohol and Ritalin and codeine ... You, you as well, you are the monster that testosterone is awakening in me. (p. 398).

Our hope here is to begin to contemplate what this new "era," this new "stage of capitalism," means on the ground of education as scholars both unpack these issues and teach students who are themselves "like me," ingesting substances intimately tied to histories and futures. We are, it would seem, consumers who are becoming subjects in the midst of a time where education is viewed as a consumer-good and where we, as subjects are the consumers of pharmaceuticals. How do our shared realities amidst this consumption alter our task as educators to contemplate studentsbecoming-subjects?

\section{References}

Becker, H. (1963). Outsiders: Studies in the sociology of deviance. New York, NY: The Free Press. 
Bergalli, R. (1980). Origen de las teorías de la reacción social. Un aporte al análisis y crítica del labelling approach [Origin of the theories of social reaction. A contribution to the analysis and critique of the labelling approach]. Papers: Revista de Sociologia, 13, 49-96.

Castel, R. (1973). Le psychoanalysme [The psychoanalysm]. Paris, France: Flamarion.

Deleuze, G., \& Guattari, F. (1975). Kafka: Pour une littérature mineure. Paris: Minuit [English version: (1986)]. Kafka: Toward a minor literature (Theory and history of literature). Minneapolis, MN: The University of Minnesota Press.

Deleuze, G., \& Parnet, C. (1977). Dialogues. Paris, France: Flammarion [English version: (1987)]. Dialogues. New York, NY: Columbia University Press.

Dumit, J. (2012). Drugs for life: How pharmaceutical companies define our health. Durham, NC: Duke University Press.

Foucault, M. (1961). Folie et déraison. Histoire de la folie à l'âge classique. Paris, France: Le Plon. [English version: (2006)]. History of madness. New York, NY: Routledge.

Foucault, M. (1975). Surveiller et punir. Naissance de la prison. Paris, France: Gallimard [English version: (1975)]. Discipline and punish: The birth of the prison. New York, NY: Random House.

Foucault, M. (1976). Histoire de la sexualité. Vol. 1: La volonté de savoir. Paris, France: Gallimard [English version: (1978)]. The history of sexuality. Volume I: An introduction. New York, NY: Random House.

Foucault, M. (1984). Le sujet et le pouvoir. In H. Dreyfus, P. Rabinov (Eds.). Michel Foucault, un parcours philosophique. Au-delà de l'objectivité (pp. 297-321). Paris, France: Gallimard [English version: (1983)]. The subject and power. In H. Dreyfus, P. Rabinov (Eds.). Michel Foucault: Beyond structuralism and hermeneutics (pp. 208-226). Chicago, IL: The University of Chicago Press.

Foucault, M. (1994). Dits et écrits, 1954-1988. Vol. 2: 1970-1975. Paris, France: Gallimard [English version: (1998)]. Ethics: Subjectivity and truth. New York, NY: The New Press.

Goffman, E. (1961). Asylums. Essays on the social situation of mental patients and other inmates. New York, NY: Anchor Books/Random House.

Goffman, E. (1963). Stigma: Notes on the management of spoiled identity. Upper Saddle River, NJ: Prentice-Hall. 
Gramsci, A. (1975). Quaderni del carcere. Turin, Italy: Einaudi [English version: (1971)]. Selections from the Prison Notebooks. New York, NY: International Publishers.

Horwitz, A. V. (2010). Pharmaceuticals and the medicalization of social life. In D. W. Light (Ed.), The risks of prescription drugs (pp. 92-115). New York, NY: Columbia University Press.

Knobel Freud, J. (2013). El reto de ser padres [The challenge of being parents]. Barcelona. Spain: Ediciones B.

Marxen, E. (2008). Therapeutic thinking in contemporary art. Psychotherapy in the arts. The Arts in Psychotherapy, 36, 140-147. http://dx.doi.org/10.1016/j.aip.2008.10.004 (printed [2009] The Arts in Psychotherapy).

Marxen, E. (2009). La etnografía desde el arte. Definiciones, bases teóricas y nuevos escenarios [Ethnography from art. Definitions, theoretical bases and new sceneries]. Alteridades, 19(37), 7-22.

Marxen, E. (2011). Diálogos entre arte y terapia. Del 'arte psicótico' al desarrollo de la arteterapia y sus aplicaciones [Dialogues between art and therapy. From 'psychotic art' to the development of art therapy and its applications]. Barcelona, Spain: Gedisa.

Marxen, E. (2012). 'La comunidad silenciosa'. Migraciones Filipinas y capital social en el Raval (Barcelona) ['The silent community'. Filipino migrations and social capital at Rava (Barcelona)]. PhD thesis. Online publication: Tarragona, Spain: University Rovira i Virgili. http://www.tdx.cat/bitstream/handle/10803/96667/TESIS.pdf?seq uence $=1$.

Marxen, E. (2016). La expresión veraz de los saberes corporeizados [The fearless expression of embodied knowledges]. In I. A. Hernández, F. Grijalva Maza, \& A. R. Gómez Rossi (Eds.), Más allá del texto. Cultura digital y nuevas epistemologías [Beyond the text. Digital culture and new epistemologies]. Mexico City, Mexico: Editorial Itaca.

Marxen (2017). Art therapy. In N. Sajnani, E. Marxen, \& R. Zarate. (2017). Critical perspectives in the arts therapies: Response/ability across a continuum of practice. The Arts in Psychotherapy 54, 28-37. DOI: 10.1016/j.aip.2017.01.007.

Marxen, E., \& Rodríguez, M. (2012). Alleged opposites: On the public sphere, art and the clinic. Research working group. Retrieved from: http://www.macba.cat/en/alleged-opposites.

Negri, T., \& Guattari, F. (1996). Las verdades nómadas [Nomadic truths]. Irun, Spain: Iralka. 
Olson-Kennedy, J., Rosenthal, S. M., Hastings, J. \& Wesp, L. (2018). Health considerations for gender non-conforming children and transgender adolescents. UCSF Center of Excellence for Transgender Health. Retrieved from http://transhealth.ucsf.edu/trans?page=guidelinesyouth.

Oury, J., Guattari, F., \& Tosquelles, F. (1985). Pratique de l'Institutionnel et politique [Practice of the institutional and political]. Vigneux, France: Matrice Editions.

Pizza, G. (2005). Antonio Gramsci y la antropología médica contemporánea. Hegemonía, 'capacidad de actuar' (agency) y transformaciones de la persona [Antonio Gramsci and medical anthropology today. Hegemony, agency and transforming persons]. Revista de Antropología Social, 14, 15-32.

Preciado, P. (2013). Testo junkie: Sex, drugs and biopolitics in the pharmacopornographic era. New York, NY: The Feminist Press.

Rolnik, S. (2001). ¿El arte cura? [Does the art cure?]. Barcelona, Spain: Macba.

Taussig, M. (1992). Reification and the consciousness of the patient. In M. Taussig (Ed.), The nervous system (pp. 83-109). New York, NY and London, UK: Routledge.

Valverde Eizaguirre, M. A. (2015). El arte de hacer visible lo invisible: el marketing en el TDAH [The art of making the invisible visible: The ADHD marketing]. Norte de Salud Mental, 13(52), 11-26.

Winnicott, D. W. (1971). Playing and reality. London, UK and New York, NY: Tavistock/Routledge.

Winnicott, D. W. (1984). Deprivation and delinquency. London, UK and New York, NY: Tavistock. 